\title{
Market Competition and Agency Problem: a Study in Indonesian Manufacturing Companies
}

\section{Ahmad Cahyo Nugroho ${ }^{1}$, Jol Stoffers ${ }^{2}$}

Marketing management for Electronic Industry, Politeknik APP Jakarta, Ministry of Industry, Indonesia ${ }^{1}$ Research Centre for Employability, Zuyd University of Applied Sciences, The Netherlands, Research Centre for Education and the Labour Market (ROA), Maastricht University, The Netherlands ${ }^{2}$

\section{Info Article}

History Article:

Submitted 30 October 2019

Revised 15 November 2019

Accepted 11 December 2019

Keywords:

Agency Theory; Market Competition; Investment Decision; Manufacturing; Indonesia.

\begin{abstract}
This research examines the relationship between firm investment and market competition, market position and market position as market leader. This study analyzes agency problems in manufacturing companies' investment decisions by considering market competition, since market competition is considered as one of essential factor that affect the firm investment. Further, high competition signals company's increased investment, that leads to business efficiency. Investment decisions are important for companies to survive, and more competitive companies are likely to conduct more risky activities, especially regarding capital expenditures for investments. This study uses the dynamic panel data method, which includes annual financial report of 100 listed manufacturing companies on IDX from 2007 to 2016. The companies were selected after sorting using several criteria, such as completeness of financial report and being registered on IDX during the period. Results suggest that leverage improves management control functions, and competition increases a company's investments to maintain its position in the market. Competition is not strengthened or weakened by sales growth and there are indications of herding behavior following market leaders.
\end{abstract}

\section{Persaingan Pasar dan Pemasalahan Keagenan: Studi Kasus di Perusahaan Manufaktur di Indonesia}

\begin{abstract}
Abstrak
Penelitian ini menguji hubungan antara investasi perusahaan terhadap kompetisi pasar, posisi pasar dan posisi pasar sebagai peimimpin pasar. Studi ini menganalisis masalah keagenan selama keputusan investasi perusahaan manufaktur dengan mempertimbangkan persaingan pasar karena persaingan pasar dianggap sebagai salah satu faktor penting dalam keputusan investasi perusahaan. Terlebih, persaingan yang ketat menunjukkan peningkatan investasi perusahaan yang mengarah pada efisiensi perusahaan. Keputusan investasi penting bagi perusahaan untuk bertahan, dan perusahaan yang berada dipasar yang lebih kompetitif cenderung melakukan kegiatan yang lebih berisiko, terutama mengenai pengeluaran modal untuk investasi. Penelitian ini menggunakan metode data panel dinamis, dengan menggunakan laporan keuangan tahunan dari 100 sampel perusahaan manufaktur yang terdaftar dalam Bursa Efek Indonesia dari tahun 2007 hingga 2016. Perusahaan-perusahaan tersebut dipilih setelah melalui proses penyortiran dengan menggunakan beberapa kriteria seperti kelengkapan laporan keuangan dan telah terdaftar di Bursa Efek Indonesia (BEI).Hasil menunjukkan bahwa leverage meningkatkan fungsi kontrol manajemen, dan persaingan meningkatkan investasi perusahaan untuk mempertahankan posisinya di pasar. Persaingan tidak diperkuat atau dilemahkan oleh pertumbuhan penjualan dan terdapat indikasi pola mengikuti pemimpin pasar.
\end{abstract}

JEL Classification: D4, L6

How to Cite: Nugroho, A. C., \& Stoffers, J. (2020). Market Competition and Agency Problem: a Study in Indonesian Manufacturing Companies. Jurnal Dinamika Manajemen, 11(1), 65-77. 


\section{INTRODUCTION}

Corporate investment decisions affect a company's performance; investment can enhance company performance because the profit from investment increases can increase profitability (Fama \& French, 1998; Chen et al., 2014). Increased investment also increases national income (Ernita et al., 2013). As a developing country, Indonesia is trying to attract investors to develop the manufacturing sector in increasing gross domestic product (GDP). In 2015, manufacturing contributed 490,470 billion rupiahs, or $22 \%$, to GDP, based on the 2010 constant value. Manufacturing industries have a high level of employment in Indonesia. Manufacturing sector performance affects exports and the economy. People who worked in manufacturing in 2015 reached 16.3 million people, or $13.6 \%$, of the total workforce (Badan Pusat Statistik, 2017).

In agency theory, market competition, corporate governance, and capital structure are essential factors that influence company investment decisions (Nugroho et al., 2018). Investment is a critical aspect in any company which determines a company's survival and include decisions related to capital investment and research and development (McConnell \& Muscarella, 1985; Lang et al., 1996; Aivazian et al., 2005). Empirical evidence has shown the relationship between competition and investment, how a company decides the source of financing, and choice of investments made influenced by market competition experienced by the company (Haushalter et al., 2007; Xu, 2012).

Competition itself is essential for the growth of a business because competition leads to business efficiency (Stoughton et al., 2017). Also, the competition allows companies to optimize the performance of managers so the company can win competition against its competitors (Laksmana \& Yang, 2015). Product market competition can reduce the cost of equity capital, which means that with agency competition, investment will become more efficient (Chen et al., 2014). increasing product market competition would increase efficiency and financing in labor-intensive industries (Lin et al., 2011). There is a positive relationship between product market competition and corporate investment in countries with strong and predictable economies such as China (Chen et al., 2017).

The problem of information asymmetry between managers and financial institutions, and agency conflicts between managers and shareholders, in manufacturing companies affect a company's investment decisions are empirically in many studies. One that determines the profits generated by the company is the right investment decision, which in turn influences company value (Karuna, 2007; Laksmana \& Yang, 2015). Investment decisions often associated with agency problems and information asymmetry can emerge as rational responses to product-market competition (Akdoĝu \& MacKay, 2012). Market competition influences investment decisions and leads to business efficiency. Under competition, managers are encouraged to carry out their duties in maintaining the sustainability of the company (Alimov, 2014).

Empirical evidence suggests that competitive pressures influence corporate investment decisions. Because in business cycles, investment decisions not only affect the company's cash flow but also affect the company's level of cash flow stability (Mello \& Wang, 2012). Based on the Indonesian Stock Exchange (IDX) data, average investments along with the Herfindahl-Hirschman index (HHI) ranges ( 0.1 to 0.9 ), where smaller $\mathrm{HHI}$ indicates greater competition between companies. Declining HHI suggests greater competition, indicating that investment in manufacturing companies is increasing. High competition signals a company's increased investment, which is essential to explain in research, with a need to consider market competition when companies make investment decisions. 
Ahmad Cahyo Nugroho \& Jol Stoffers/ Market Competition and Agency Problem: a Study ...

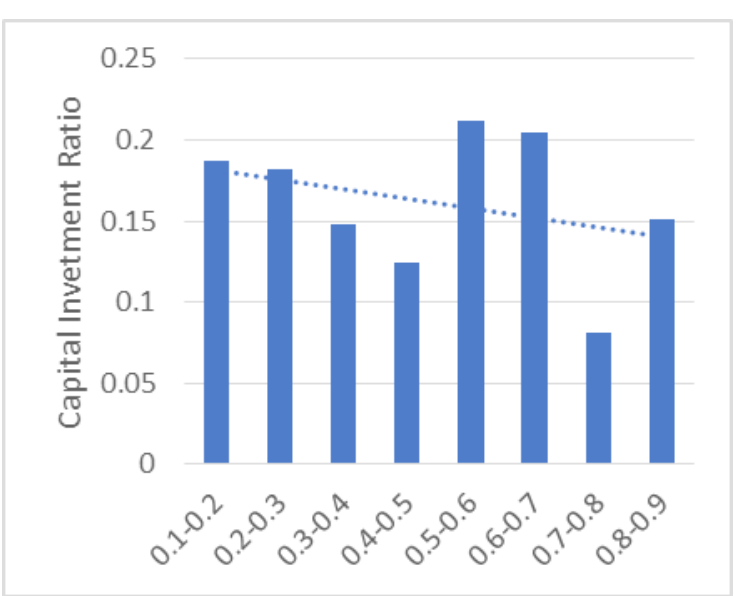

Figure 1. Average investment (ratio of fixed assets at the beginning of the year) and a range of HHI values.

Figure 1 shows the average value of investment in several HHI ranges (0.1-0.9), where the smaller the value of $\mathrm{HHI}$ indicates, the higher the competition. The downward trend in HHI data shows that the higher the competition (HHI is decreasing), indicating that investment in manufacturing companies is increasing

There are different paradigms in implementing agency theory, and those paradigms are the company's strategic behavior; principalagent contract structure; Monitoring and strengthening of principal-agent contracts; The evolutionary process that changes the structure of the principal-agent contract and the structure of the institution that issued the contract (Hill 1992). In his study, it found that differences in market conditions resulted in inconsistent results, by analyzing various paradigms, it could provide more comprehensive results in the application of agency theory.

The application of agency theory called into doubt applied to non-anglo-Saxon culture companies in and to companies that are in emerging markets (Sundaramurthy \& Lewis, 2003; Bruce et al., 2005; Young et al., 2008; Mutlu et al., 2016). Agency theory works based on the assumption that markets are efficient and adjusts changes that occur quickly (Hill \& Jones, 1992). Several studies have shown that Indonesia is in an inefficient market and has a weak form in market efficiency (Worthington
\& Higgs, 2004). The novelty of this research is to examine the implementation of agency theory in an Indonesian condition where companies do not grow in the context of Anglo-Saxon culture and inefficient market conditions using the paradigm of the company's strategic behavior by using competition indicators that affect the company's environmental conditions in inefficient market conditions such as in Indonesia to produce consistent results on agency theory study.

\section{Hypothesis Development}

Agency relationships discuss the information asymmetry problem between managers and financial institutions and agency conflicts between controlling shareholders and minority investors and between managers and shareholders, has a significant effect on a company's investment decisions (Myers \& Majluf, 1984; Jensen, 1986; Fazzari et al., 1988). The risk of a business determined by the level of investment that the firm made (Gale \& Hellwig, 1985).

In traditional Industrial Organization economics, the structure-conduct-performance paradigm has accepted in the strategic management discipline(McWilliams \& Smart, 1993). The negative uncertainty sensitivity of investment is increased by industry concentration but decreased by market share. The latter finding supports the view of the strategic investment behavior of rival firms under uncertainty (Shima, 2016). Market structure impact on investment in the European mobile industry indicated by the significant effects of the number of companies and market share asymmetry on investment (Jeanjean \& Houngbonon, 2017).

Competition plays a role in corporate governance, in which market competition increases investment through management discipline and strengthens corporate governance (Grosfeld \& Tressel, 2002; Chen et al., 2012; Jiang et al., 2015; Laksmana \& Yang, 2015). Product market competition can be measured using three variables-the number of participants or companies in an industry, a concentration ratio (CR4), and HHI (Karuna, 2007; Li, 2010; 
Chen et al., 2012; Jiang et al., 2015). Product market competition also influenced corporate investment and financing behaviors, that explain the role of competition across market structures, finding that greater competition results in less investment (Cheung, 2013).

Competition reduces agency problems by disciplining managers to prevent overinvestment in positive free cash flow (Laksmana \& Yang, 2015). Competition from foreign competitors triggered by trade liberalization influences a company's investment. Results suggest that U.S. companies reduced capital and R\&D investments significantly and accumulated cash reserves in response to a reduction in import tariffs, which resulted in increased foreign competition. The study highlights that trade globalization and competition determine U.S. companies' investment choices (Frésard \& Valta, 2013).

Product market competition makes institutional investors invest in companies more efficiently, which shows the influence of product market competition on corporate investment efficiency in terms of corporate governance (Stoughton et al., 2017). In examining the relationship between product market competition and management investment decisions, specifically on corporate risk-taking and investment efficiency. Higher competition provides protection for shareholders from efforts to divert company resources by managers for personal gain. As a result, when shareholder protection is high, management tends to invest in risky projects. On the other hand, competition makes managerial decision results more easily observable because company performance can evaluate relative to competitors. Based on the description, the proposed first hypothesis is:

$\mathrm{H} 1$ : The market competition has a positive effect on firm investment.

In traditional Industrial Organization economics, the structure-conduct-performance paradigm has accepted in the strategic management discipline(McWilliams \& Smart, 1993). The negative uncertainty sensitivity of invest- ment is increased by industry concentration but decreased by market share. The latter finding supports the view of the strategic investment behavior of rival firms under uncertainty (Shima, 2016). Market structure impact on investment in the European mobile industry indicated by the significant effects of the number of companies and market share asymmetry on investment (Jeanjean \& Houngbonon, 2017). Based on the description, the proposed second and third hypothesis is:

$\mathrm{H} 2$ : Higher market position on sales growth has a positive effect on firm investment.

H3 : Market position as a market leader has a negative effect on firm investment.

\section{METHOD}

This study uses dynamic panel data regression to assess the effect of agency problems considering market competition conditions. Some studies suggest that investment decisions are influenced by several factors, one of which is investments made in the previous year. A company's investments represent both new investments and maintenance costs from previous ones (McGrattan, 1999). Annual financial reports were obtained from 100 companies in the manufacturing sector and listed on IDX for the period 2007 to 2016 . These companies were selected after sorting/selection using several criteria, such as completeness of reported financial data and being registered on IDX during the period.

First Stage, a base model was constructed, a model modified from extant studies (Aivazian et al., 2005; Chen et al., 2012; Chen et al., 2014; Jiang et al., 2015) using five independent variables: $\mathrm{I}_{\mathrm{it}-1}, \mathrm{CF}_{\mathrm{it}}, \mathrm{TQ}_{\mathrm{t} t-1}, \mathrm{Lev}_{\mathrm{it}}$ and Sale $\mathrm{it}_{\mathrm{it}-1}$ to investigate the investment decisions $\left(\mathrm{I}_{t}\right)$ of manufacturing companies.

$$
\begin{aligned}
\mathrm{I}_{\mathrm{it}}= & \gamma_{0}+\gamma_{1} \mathrm{I}_{\mathrm{it}-1}+\gamma_{2} \mathrm{CF}_{\mathrm{it}}+\gamma_{3} \mathrm{TQ}_{\mathrm{t}-1}+\gamma 4 \mathrm{Lev}_{\mathrm{it}-1}+ \\
& \gamma_{5} \mathrm{Sale}_{\mathrm{it}-1}+\varepsilon_{\mathrm{it}} \gamma_{1}>0, \gamma_{2}>0, \gamma_{3}>0, \gamma_{4}<0, \gamma_{5}>0
\end{aligned}
$$

For the second stage, a more detailed model constructed to assess the effect of product 
Ahmad Cahyo Nugroho \& Jol Stoffers/ Market Competition and Agency Problem: a Study ...

market competition on investment decisions. $\mathrm{HHI}_{\text {it-1 }}$ was used to examine whether competition affects Indonesian manufacturing companies' investment decisions. This study use Sales growth $\left(\mathrm{HSGr}_{\mathrm{it-1}}\right)$ to proxy signals companies to invest. Interaction between $\mathrm{HSGr}_{\text {it-1 }}$ with $\mathrm{HHI}_{\text {it-1 }}$ in the model is to assess whether sales growth $\left(\mathrm{HSGr}_{\mathrm{it-1}}\right.$ ) strengthens or weakens the influence of product market competition $\left(\mathrm{HHI}_{\mathrm{it}-1}\right)$ on investment decisions (I).

Market leaders delay investments because they are superior to competitors (Akdogi \& MacKay, 2012); if market leader investments exceed competitors', the company delays investment. The HLeader ${ }_{\text {it-1 }}$ variable interacts with $\mathrm{HHI}_{\mathrm{it}-\mathrm{1}}$ to assess whether the position of a company as a market leader strengthens or weakens the influence of product market competition $\left(\mathrm{HHI}_{\mathrm{it}-\mathrm{I}}\right)$ on investment decisions (I). Variab- les used in this study proxy agency problems by considering market competition. Table 1 shows the operational variable definition used in this study.

$$
\begin{aligned}
\mathrm{I}_{\mathrm{it}}= & \alpha_{0}+\alpha_{1} \mathrm{I}_{\mathrm{it}-1}+\alpha_{2} \mathrm{CF}_{\mathrm{it}}+\alpha_{3} \mathrm{TQ}_{\mathrm{it}}+\alpha_{4} \mathrm{Lev}_{\mathrm{it}}+\alpha_{5} \\
& \mathrm{Sale}_{\mathrm{it}-1}+\alpha_{6} \mathrm{HHI}_{\mathrm{it}-1}+\alpha_{7} \mathrm{HSGr}_{\mathrm{it}-1}+\alpha_{8} \mathrm{HLea} \\
& \text { der }_{\text {it-1 }}+\alpha_{9} \mathrm{HHI}_{\mathrm{it}-1} \mathrm{HSGr}_{\mathrm{it}-1}+\alpha_{10} \mathrm{HHI}_{\mathrm{it}-} \\
& { }_{1}^{*} \mathrm{HLeader}_{\mathrm{it}-1}+\varepsilon_{\mathrm{it}}
\end{aligned}
$$

Notes:

$\alpha_{1}>0, \alpha_{2}>0, \alpha_{3}>0, \alpha_{4}<0, \alpha_{5}>0, \alpha_{6}<0, \alpha_{7}>0, \alpha_{8}<0$, $\alpha_{9} \neq 0, \alpha_{10} \neq 0$

\section{RESULT AND DISCUSSION}

\section{Descriptive Statistics}

Descriptive statistics were obtained

\begin{tabular}{|c|c|c|}
\hline Indicator & Definition & References \\
\hline I & $\begin{array}{l}\text { Net investment }(\mathrm{I}) / \mathrm{lag} \text { of net assets }(\mathrm{K})=(\text { Capital ex- } \\
\text { penditure-Depreciation }) / \mathrm{lag} \text { of fixed assets }\end{array}$ & $\begin{array}{l}\text { (Fazzari et al., 1988; Lang et al., } \\
\text { 1996; Aivazian et al., 2005) }\end{array}$ \\
\hline $\mathrm{CF}$ & $\begin{array}{l}\text { Operational cash flow divided by the book value of assets } \\
\text { at the beginning of the year }\end{array}$ & $\begin{array}{l}\text { (Fazzari et al., 1988; Lang et al., } \\
\text { 1996; Chen et al., 2012; Jiang et al., } \\
\text { 2015) }\end{array}$ \\
\hline TQ & $\begin{array}{l}\text { (Market value in equity-book value in equity+book val- } \\
\text { ue on assets)/divided by book value on assets. }\end{array}$ & $\begin{array}{l}\text { (Modigliani \& Miller, 1963; Chen } \\
\text { et al., 2012) }\end{array}$ \\
\hline Leverage & Total liabilities/total assets & $\begin{array}{l}\text { (Opler \& Titiman, 1994; Lang et } \\
\text { al., 1996; Aivazian et al., 2005) }\end{array}$ \\
\hline Sale & Sales/fixed assets at the beginning of the year & $\begin{array}{l}\text { (Lang et al., 1996; Aivazian et al., } \\
\text { 2005) }\end{array}$ \\
\hline HHI & $\begin{array}{l}\text { Total of square market share for all companies in the } \\
\text { same industry and listed on IDX. The market share of a } \\
\text { company is the ratio of company sales to industry sales }\end{array}$ & $\begin{array}{l}\text { (Rubinstein \& Tirole, 1989; San- } \\
\text { talo \& Becerra, 2008; Jiang et al., } \\
\text { 2015) }\end{array}$ \\
\hline HSGr & $\begin{array}{l}\text { Dummy variable }=1 \text { if the company's sales growth from } \\
\text { the beginning of the year to the end of the year at } t-1 \text { is } \\
\text { greater than the mean sales growth of the company dur- } \\
\text { ing the same period and in the same industry, and zero } \\
\text { otherwise }\end{array}$ & (Jiang et al., 2015) \\
\hline LEADER & $\begin{array}{l}\text { Dummy variable }=1 \text {, if company sales are higher than } 5 \% \\
\text { of industry sales at the end of the previous year, and zero } \\
\text { otherwise }\end{array}$ & (Jiang et al., 2015) \\
\hline
\end{tabular}
from 100 IDX manufacturing companies for the period 2007 to 2016, which generated

Table 1. Operational Variable Definition 
1000 observations. Table 2 shows that the average investment for the sample was 0.1227 $(\mathrm{SD}=0.3558)$, with a median of 0.0387 and a maximum and minimum of 5.7832 and -0.9327 , respectively. The average CF was $0.3269(\mathrm{SD}=0.7694)$, average TQ was 1.4999 $(\mathrm{SD}=1.7610)$, average sales were $5.0351(\mathrm{SD}$ $=5.7678)$, and average leverage was 0.5426 $(S D=0.4111)$. High sales found for SSTM (Sunson Textile Manufacturer), a company that produces cotton yarn. Its sales (i.e., the ratio of fixed assets at the beginning of the year) was always above 25 , reaching its zenith in 2011 at 50.3166, a result of marketing its pro- ducts not only domestically, but exporting to Asia, Europe, the Americas, and Africa.

Table 3 shows average investment, cash flow, Tobin's q ratio, sales, and leverage for the sample. Average investment (i.e., the ratio of fixed assets at the beginning of the year) peaked in 2011 at 0.1655 and was lowest in 2016 at 0.0575 . There were changes to investment across subsectors (i.e., basic and chemical industries, various industries, and consumer goods industries).

Average investment in the various industries subsector (i.e., ratio of fixed assets at the beginning of the year) was highest at 0.2161 , fol-

Table 2. Descriptive Statistics

\begin{tabular}{lrrrrr}
\hline & \multicolumn{1}{c}{ Investment } & \multicolumn{1}{c}{ CF } & \multicolumn{1}{c}{ TQ } & \multicolumn{1}{c}{ Sales } & \multicolumn{1}{c}{ Lev } \\
\hline Average & .1227 & .3269 & 1.4999 & 5.0351 & .5426 \\
Median & .0387 & .1772 & 1.0407 & 3.4608 & .4989 \\
Maximum & 5.7832 & 6.0712 & 18.9424 & 50.3166 & 3.3696 \\
Minimum & -.9327 & -5.4432 & -2.2986 & .0331 & .0001 \\
Standard Deviation & .3558 & .7694 & 1.7610 & 5.7678 & .4111 \\
\hline
\end{tabular}

Notes:

Investment: Ratio to fixed assets at the beginning of the year.

Cash flow: Ratio to fixed assets at the beginning of the year.

Sales: Ratio to fixed assets at the beginning of the year.

Leverage: Ratio to total assets.

Table 3. The Average Value in the Manufacturing Industry for Each Variable

\begin{tabular}{llllll}
\hline Year & Investment & CF & TQ & Sales & Lev \\
\hline 2008 & .1065 & .2631 & 1.0689 & 6.4144 & .5992 \\
2009 & .0976 & .4289 & 1.1882 & 5.0287 & .5567 \\
2010 & .0877 & .3559 & 1.4713 & 5.5400 & .5244 \\
2011 & .1655 & .3338 & 1.5479 & 6.6946 & .5140 \\
2012 & .1602 & .3310 & 1.7243 & 6.0522 & .5008 \\
2013 & .1518 & .3412 & 1.7768 & 5.5556 & .5239 \\
2014 & .1354 & .2121 & 1.8102 & 5.1424 & .5287 \\
2015 & .1424 & .3782 & 1.5810 & 4.4889 & .5348 \\
2016 & .0575 & .2983 & 1.8552 & 4.2342 & .5072 \\
\hline
\end{tabular}

Notes:

Investment: Ratio to fixed assets at the beginning of the year.

Cash flow: Ratio to fixed assets at the beginning of the year.

Sales: Ratio to fixed assets at the beginning of the year.

Leverage: Ratio to total assets. 
Ahmad Cahyo Nugroho \& Jol Stoffers/ Market Competition and Agency Problem: a Study ...

lowed by basic and chemical industries at 0.1614 and consumer goods industries at 0.1291 . These disparities caused by the companies' many internal and external factors (Table 4). cash flow increases with the degree of corporate governance. Companies that have weak governance have difficulties obtaining external funding, so they focus on internal financing.

Table 4. Industrial Investment by Sub-Sector (Ratio of Fixed Assets at the Beginning of the Year)

\begin{tabular}{llll}
\hline Year & $\begin{array}{l}\text { Basic and Chemical } \\
\text { Industries }\end{array}$ & Various Industries & $\begin{array}{l}\text { Consumer Goods } \\
\text { Industries }\end{array}$ \\
\hline 2008 & .0138 & .1938 & .1505 \\
2009 & .1609 & .0344 & .0717 \\
2010 & .0619 & .1008 & .1129 \\
2011 & .1484 & .2059 & .1458 \\
2012 & .1652 & .1424 & .1729 \\
2013 & .1475 & .1364 & .1762 \\
2014 & .0999 & .1767 & .1430 \\
2015 & .0514 & .3094 & .0923 \\
2016 & .0434 & .0526 & .0850 \\
Average & .1614 & .2161 & .1291 \\
Median & .1237 & .1595 & .1420 \\
Standard Deviation & .2044 & .2228 & .0366 \\
Total Firms & 42 & 30 & 28 \\
\hline
\end{tabular}

\section{Agency Problems and Investment Decisions}

The first stage of this research is to obtain empirical evidence of agency problems and the dynamic pattern of investment in manufacturing companies in Indonesia using the basic model based on previous research to determine the control variables.

The result in Table 5 shows that investment $_{\mathrm{t}-1}$ had a positive effect on manufacturing companies' investments, a finding that verifies Demarzo et al. (2012), who argue that investments relate positively to the previous year's investments requiring an optimal contract between investors and the company's management to minimize costs of agency problems. Optimal contracting includes deferred compensation, possible termination, and compensation that be subject to exogenous observable and persistent profitability shocks (Demarzo et al., 2012; Salitskiy, 2013).

This study uses cash flow as one of the control variables. Investment sensitivity to
Table 5. Estimation results of the agency problem model on investment in Indonesian manufacturing companies

\begin{tabular}{|c|c|}
\hline Variable & Base Model \\
\hline Investment $_{\mathrm{it}-1}$ & $.0093^{* * *}$ \\
\hline $\mathrm{CF}_{\mathrm{it}}$ & $.0779^{* * *}$ \\
\hline $\mathrm{TQ}_{\mathrm{t}-1}$ & $.0196^{* * *}$ \\
\hline Sales $_{\text {it-1 }}$ & $.0364^{* * *}$ \\
\hline $\operatorname{Lev}_{\mathrm{it}-1}$ & $-.3027^{* * *}$ \\
\hline Cons & .0294 \\
\hline Sargan (Prob) & .4250 \\
\hline Arelano bond M1 (Prob) & .0138 \\
\hline Arelano bond M2 (Prob) & .1392 \\
\hline Investasi $_{\mathrm{t}-1}(\mathrm{FEM})$ & .0024 \\
\hline Investasi $_{\mathrm{t}-1}(\mathrm{PLS})$ & .0094 \\
\hline
\end{tabular}

Notes:

${ }^{*},{ }^{* *},{ }^{* * *}$ symbol indicates significance at the level of $10 \%$, $5 \%, 1 \%$

Base model: the effect of agency problems on investment decisions in manufacturing companies 
Under these limitations, investment decisions of companies that have financial constraints are more sensitive to liquidity. Financial constraints are more evident in companies with higher information opacity, companies with financial misreporting, and moderated by institutional ownership (Lin et al., 2011).

Table 5 shows that $\mathrm{CF}_{\text {it }}$ had a positive influence on investments; the greater the cash flow, the more a company's liquidity influenced increased company investment. These results verify that high cash flows result in greater investments. High cash flows increase conflicts of interest between managers and shareholders, where managers tend to use cash for asset investment rather than distributing it as dividends. Asymmetric information triggers companies to use cash flows to finance capital expenditures (i.e., investment) as desired. These results support previous studies that have examined the relationship between cash flow and investment (Fazzari et al., 1988; Jiang et al., 2015; Chen et al., 2016).

This research uses $\mathrm{TQ}_{\mathrm{it}-1}$ as proxies for investment opportunities through capital market financing, which hypothesized influenced investments positively. Investment opportunities increase the use of equity financing that represents lower potential constraints to managers, thus giving them increased flexibility in current investments and future financing plans and increases asymmetric information in companies (Martin, 1996). The results of this study confirm that argument by the positive relationship between investment opportunities from equity financing and company investment

Sales $_{\text {it-1 }}$ proxies market demand, which had a positive influence on investments. If market demand increases, a company receives more revenue, which is used for additional investment, so investments increase. The relationship between competition and return on assets varies depending on market demand for the product; when demand is low, companies in an industry are more competitive to achieve higher profits, and if demand is high, higher returns are realized (Aguerrevere, 2009), and new information about company fundamentals (e.g., sales growth) signals investment incentives, so a company's investments increase (Fuss \& Vermeulen, 2008).

Leverage $_{\text {it-1 }}$ had a negative influence and the highest coefficient at -0.3027 , which indicates that the role of leverage as management control in manufacturing companies is high, especially at reducing agency problems. Managers tend to expand the size of a company and pay less attention to the value of the company after investment, even investing in projects that are undesirable and reduce shareholders' welfare.

The availability of cash flow limits Managers' ability to implement such policies and such constraints further tightened through debt financing. Debtholders also monitor company performance and business decisions, including investment decisions due to leverage (Firth et al., 2012). The characteristics of debt financing make managers obliged to create future returns. Martin (1996) argues that debt financing prevents managers from using cash flows to invest in unprofitable projects. Debt financing can be used to reduce agency problems that occur between managers and shareholders (Margaritis \& Psillaki, 2010).

With the company debts, managers bound to repayment obligation, and the contract specifies an obligation between the managers and lenders regarding payments and payment periods. The existence of management-binding contracts causes higher coefficients in comparison to other variables. This situation consensuses with contract theory, which suggests that contracts between agents and principals (e.g., shareholders and debtholders) encourage agents to behave in the interests of the principal (Eisenhardt, 1989).

\section{Agency Problems, Investment Decisions, and Market Competition}

Companies in competitive industries have operating advantages that are sensitive to shocks, so less competitive companies enjoy greater operational benefits. A company that is in a market that has a high level of competition will strive to maintain the sustainability of its 
Ahmad Cahyo Nugroho \& Jol Stoffers/ Market Competition and Agency Problem: a Study ...

business. On the one hand, companies will face a higher risk in investment decisions, but on the other, if they did not invest, the continuity of their business would be threatened by competitors.

Table 6 summarizes results from dynamic panel model estimation, which suggests a problem of the influence of competition on investment in Indonesian manufacturing companies. The Table divided into three specifications.

Companies that are in less competitive markets have lower dividend payout ratios (Grullon \& Michaely, 2011). Such findings corroborate that competition encourages managers to pay excess cash as dividends.

Competition directly pressures and has institutional effects on managerial efficiency, which makes a company understand the importance of improving quality (Baggs \& De Bettignies, 2007). Results in Table 6 for all specifications of the model show that $\mathrm{HHI}_{\mathrm{it}-1}$ had a negative effect on investment in manufacturing companies. Competition increase risks, causing agency problems to decrease and benefitting a company because competition improves management performance and corporate governance (Jiang et al., 2015; Laksmana \& Yang, 2015).

Competition reduces opportunities for resource transfers in the form of personal management benefits. However, the company maintains its presence in the market by maintaining a competitive position, and managers invest more profitably to maintain this competitive position. Focusing on sales growth is essential to obtaining the desired profit; companies must have sales growth to achieve sustainable performance (Brush et al., 2000). The sensitivity of investment increased by industry concentration (Shima, 2016). This result indicates a higher risk in a more concentrated industry, encourage company managers to be more cautious in making investment decisions.

Table 6. Estimation results of the influence of agency problems in investment decisions by market competition

\begin{tabular}{|c|c|c|c|}
\hline \multirow{2}{*}{ Variable } & \multicolumn{3}{|c|}{ Specification } \\
\hline & 1 & 2 & 3 \\
\hline Investment $_{\mathrm{it-1}}$ & $.0091^{* * *}$ & $.0067^{* * *}$ & $.0076^{* * *}$ \\
\hline $\mathrm{CF}_{\text {it }} \quad{ }^{\mathrm{it}-\mathrm{I}}$ & $.0753^{* * *}$ & $.0658^{* * *}$ & $.0772^{* * *}$ \\
\hline $\mathrm{TQ}_{\mathrm{t}-1}$ & $.0163^{* *}$ & $.0214^{* * *}$ & $.0199^{* * *}$ \\
\hline Sales $_{\text {it-1 }}$ & $.0356^{* * *}$ & $.0364^{* * *}$ & $.0347^{* * *}$ \\
\hline $\mathrm{Lev}_{\mathrm{it}-1}$ & $-.3041^{* * *}$ & $-.3206^{* * *}$ & $-.2784^{* * *}$ \\
\hline $\mathrm{HHI}_{\mathrm{it}-1}$ & $-.0785^{* * *}$ & $-.0929^{* * *}$ & $-.0871^{* *}$ \\
\hline D_SaleGrowth ${ }_{\text {it-1 }}$ & - & $.0447^{* * *}$ & - \\
\hline $\mathrm{HHI}_{\mathrm{it}-1}{ }^{*} \mathrm{D} \_$SaleGrowth ${ }_{\mathrm{it}-1}$ & - & .0371 & - \\
\hline$D_{-} L_{\text {Leader }}{ }_{\mathrm{it}-1}$ & - & - & $-.1191^{* * *}$ \\
\hline $\mathrm{HHI}_{\mathrm{it}-1}{ }^{*} \mathrm{D}_{-}$Leader $_{\mathrm{it}-1}$ & - & - & .0299 \\
\hline Cons & $.0664^{* * *}$ & $.0517^{* * *}$ & $.0685^{* * *}$ \\
\hline Sargan (Prob) & .3941 & .2970 & .3547 \\
\hline Arelano bond M1 (Prob) & .0143 & .0140 & .0137 \\
\hline Arelano bond M2 (Prob) & .1370 & .1549 & .1711 \\
\hline Investment $_{\mathrm{t}-1}(\mathrm{FEM})$ & .0023 & .0001 & .0016 \\
\hline Investment $_{t-1}$ (PLS) & .0092 & .0070 & .0090 \\
\hline
\end{tabular}

Notes:

*,**, ${ }^{* *}$ symbol indicates significance at the level of $10 \%, 5 \%, 1 \%$

Specifications 1: Effects of market competition on investment decisions in manufacturing companies.

Specifications 2: Differences in investment in manufacturing companies that have high sales growth

Specifications 3: Differenced in the effects as a market leader on investment in manufacturing companies 
Sales growth plays a role in top managers' perceptions, and sales growth is a goal that senior managers mention commonly (Fazzari et al., 1988). The company planning system starts with a sales target, with an emphasis on growth providing benefits (Eliasson, 1977). Agency problems indicate weak corporate governance, especially when mechanisms that can align managerial decisions with shareholder interests are underprovided, and managers used sales growth opportunities to justify investment for their own interest (Jensen, 1986).

Table 6, for specification 2 shows that $\mathrm{D}_{-}$ SaleGrowth ${ }_{\mathrm{it}-1}$ is a dummy variable for companies that had sales growth above the industry's sales average in the same sub-sector that year, and has a positive coefficient. Sales growth indicates investment opportunities for companies in the market, so companies that had above-average growth had greater opportunities to invest. Sales growth has a positive effect on company performance, encouraging companies to make more investments (Brush et al., 2000). Sales growth affects various factors, one of which is opportunities for investment in equipment and technology that enhance overall production (Kaplan \& Norton, 2007).

HHI $_{\text {it-1 }}{ }^{*} D_{\text {_S SaleGrowth }}$ it-1 represents the interaction between industry competition and average sales growth. Results for specification 2 show the interaction was non-significant, meaning that there was no difference in the effect of competition between companies that had sales above or below industry averages.

Competitors' patterns companies that have better sales growth to helped maintain competitive positions through investment. Companies that compete in the same market tend to invest in eliminating the benefits of competitor investment (Akdoĝu \& MacKay, 2012). Thus, the effect of competition on investment decisions did not differ between companies that had sales growth above and below industry averages. Profitable companies can increase investments when experiencing increased competition from new entrants in the market (Khanna \& Tice, 2000).
Table 6, for specification 3 shows that D_Leader $_{\text {it-1 }}$ had a negative coefficient. The market leader had lower investments (0.1191 units) than followers had, which corroborates Frésard and Valta (2013), who found that market leaders invest less under global competition because they have sufficient wealth to be sustainable and because the market leader has grater flexibility than its competitor. Jiang et al. (2015) found that in China, high growth means leaders are in the best position to exploit investment opportunities. They use their high capacity to maximize benefits and opportunities under high competition.

$\mathrm{HHI}_{\mathrm{it}-1}{ }^{*} \mathrm{D} \_$Leader ${ }_{\mathrm{it}-1}$ in specification 3 was non-significant, suggesting no difference in the effect of competition on investment between market leaders and followers. The leader defined as the company that has greater sales in the market (i.e., more than 5\% of the industry), and it incentivized to delay investment because it had superior capacity than followers had. Akdogu and MacKay (2012) argue that companies that want to maximize value follow up on investment decisions. Herding behaviors from competitors reduce the benefits of investments, which are thus eliminated by herding behaviors such that they do not affect investments in manufacturing companies.

\section{CONCLUSION AND RECOMMENDATION}

Agency problems occur in Indonesian manufacturing companies through cash flow variables, credits, sales, and company capital structures. Positive relationships among cash flow, Tobin q, and sales, and negative relationships between debt and investment suggest an agency problem. Increasing capital structures represents a control variable that reduces agency problems, implying that manager control plays a role in overcoming agency problems. The competition encourages companies to invest in maintaining their positions in the market and disciplines managers, but market leaders tend to hold investments, and sales growth incentivizes investment. 
Ahmad Cahyo Nugroho \& Jol Stoffers/ Market Competition and Agency Problem: a Study ...

High competition causes companies to try to maintain their positions in the market by increasing investment. Companies with high sales growth incentivized to invest, but sales growth reflects future investment opportunities, and market leaders tend to hold back on investment. Competition neither strengthened nor weakened by sales growth or a company's position in the market due to competing companies' herding behaviors. The results of this study also provide empirical evidence of how market structure can affect agency problems in a company in the context of corporate strategic decision making such as investment. However, this research does not take into account the risks of each industrial subsector and the macroeconomic impact of investment decisions. For future research, risk factor and macroeconomics dynamics considered for obtaining more conclusive results.

\section{REFERENCES}

Aguerrevere, F. L. (2009). Real Options, Product Market Competition, and Asset Returns. Journal of Finance, 64(2), 957-983.

Aivazian, V. A., Ge, Y., \& Qiu, J. (2005). The Impact of Leverage on Firm Investment: Canadian Evidence. Journal of Corporate Finance, 11, 277-291.

Akdoĝu, E., \& Mackay, P. (2012). Product Markets and Corporate Investment: Theory and Evidence. Journal of Banking and Finance, 36(2), 439-453.

Alimov, A. (2014). Product Market Competition and the Value of Corporate Cash: Evidence from Trade Liberalization. Journal of Corporate Finance, 25(April), 122-139.

Badan Pusat Statistik. (2017). Perkembangan Indeks Produksi Manufaktur 2015-2017. Jakarta: Badan Pusat Statistik.

Baggs, J., \& De Bettignies, J. E. (2007). Product Market Competition and Agency Costs. Journal of Industrial Economics, 55(2), 289-323.

Bruce, A., Buck, T., \& Main, B. G. M. (2005). Top Executive Remuneration: a View From Europe. Journal af Management Studies, 42(7), 1493-1506.

Brush, T. H., Bromiley, P., \& Hendrickx, M. (2000). The Free Cash Flow Hypothesis for Sales
Growth and Firm Performance. Strategic Management Journal, 21(4), 455-472.

Chen, C., Li, L., \& Ma, M. L. Z. (2014). Product Market Competition and the Cost of Equity Capital: Evidence from China. Asia-Pacific Journal of Accounting and Economics, 21(3), 227-261.

Chen, R., El Ghoul, S., Guedhami, O., \& Wang, H. (2017). Do State and Foreign Ownership Affect Investment Efficiency? Evidence from Privatizations. Journal of Corporate Finance, 42, 408-421.

Chen, S., Wang, K., \& Li, X. (2012). Product Market Competition, Ultimate Controlling Structure and Related Party Transactions. China Journal of Accounting Research, 5(4), 293-306.

Chen, X., Sun, Y., \& Xu, X. (2016). Free Cash Flow, Over-Investment and Corporate Governance in China. Pacific Basin Finance Journal, 37(C), 81-103.

Cheung, A. (Wai-Kong). (2013). Product Market Competition, Corporate Investment and Financing: Evidence from Cash Flow Shortfall. Social Science Research Network (SSRN) Electronic Journal, January 14, 2013.

Demarzo, P. M., Fishman, M. J., He, Z., \& Wang, N. (2012). Dynamic Agency and the Q Theory of Investment. Journal of Finance, 67(6), 2295-2340.

Eisenhardt, K. M. (1989). Agency Theory: an Assessment and Review. Academy of Management Review, 14(1), 57-74.

Eliasson, G. (1977). Competition and Market Processes in a Simulation Model of the Swedish Economy. American Economic Association, 67(1), 277-281.

Ernita, D., Amar, S., \& Syofyan, E. (2013). Analisis Pertumbuhan Ekonomi, Investasi, dan Konsumsi Indonesia. Jurnal Kajian Ekonomi, 1(2), 176-193.

Fama, E. F., \& French, K. R. (1998). Value Versus Growth: the International Evidence. Journal of Finance, 53(6), 1975-1999.

Fazzari, S. M., Hubbard, R. G., Petersen, B. C., Blinder, A. S., \& Poterba, J. M. (1988). Financing Constraints and Corporate Investment. Brookings Papers on Economic Activity, 1988(1), 141-206.

Firth, M., Malatesta, P. H., Xin, Q. \& Xu, L. (2012). Corporate Investment, Government Control, and Financing Channels: Evidence from Chi- 
na's Listed Companies. Journal of Corporate Finance, 18(3), 433-450.

Frésard, L., \& Valta, P. (2013). Competitive Pressure and Corporate Investment: Evidence from Trade Liberalization. Unpublished Thesis. Maryland: University of Maryland and HEC Paris.

Fuss, C., \& Vermeulen, P. (2008). Firms' Investment Decisions in Response to Demand and Price Uncertainty. Applied Economics, 40(18), 2337-2351.

Gale, D., \& Hellwig, M. (1985). Incentive-Compatible Debt the One-Period Problem. Review of Economic Studies, 52(4), 647-663.

Grosfeld, I., \& Tressel, T. (2002). Competition and Ownership Structure: Substitutes or Complements? Evidence from the Warsaw Stock Exchange. Economics of Transition, 10(3), 525-551.

Grullon, G., \& Michaely, R. (2011). Corporate Payout Policy and Product Market Competition. Social Science Research Network Electronic Journal, March, 2011.

Haushalter, D., Klasa, S., \& Maxwell, W. F. (2007). The Influence of Product Market Dynamics on a Firm's Cash Holdings and Hedging Behavior. Journal of Financial Economics, 84(3), 797-825.

Hill, C. W. L., \& Jones, T. M. (1992). StakeholderAgency Theory. Journal of Management Studies, 29(2), 131-154.

Jeanjean, F., \& Houngbonon, G. V. (2017). Market Structure and Investment in the Mobile Industry. Information Economics and Policy, 38(March), 12-22.

Jensen, M. (1986). American Economic Association Agency Costs of Free Cash Flow, Corporate Finance, and Takeovers. American Economic Review, 76(2), 323-329.

Jiang, F., Kim, K. A., Nofsinger, J. R., \& Zhu, B. (2015). Product Market Competition and Corporate Investment: Evidence from China. Journal of Corporate Finance, 35(December), 196-210.

Kaplan, R. S., \& Norton, D. P. (2007). Using the Balanced Scorecard as a Strategic Management System. Harvard Business Review, 74(1), 1-15.

Karuna, C. (2007). Industry Product Market Competition and Managerial Incentives. Journal of Accounting and Economics, 43(2-3), 275-297.
Khanna, N., \& Tice, S. (2000). Strategic Responses of Incumbents to New Entry: The Effect of Ownership Structure, Capital Structure, and Focus. Review of Financial Studies, 13(3), 749-779.

Laksmana, I., \& Yang, Y. W. (2015). Product Market Competition and Corporate Investment Decisions. Review of Accounting and Finance, 14(2), 128-148.

Lang, L., Ofek, E., \& Stulz, R. M. (1996). Leverage, Investment, and Firm Growth. Journal of Financial Economics, 40(1), 3-29.

Li, X. (2010). The Impacts of Product Market Competition on the Quantity and Quality of Voluntary Disclosures. Review of Accounting Studies, 15(3), 663-711.

Lin, C., Ma, Y., \& Xuan, Y. (2011). Ownership Structure and Financial Constraints: Evidence from a Structural Estimation. Journal of Financial Economics, 102(2), 416-431.

Margaritis, D., \& Psillaki, M. (2010). Capital Structure, Equity Ownership and Firm Performance. Journal of Banking and Finance, 34(3), 621-632.

Martin, K. J. (1996). The Method of Payment in Corporate Acquisitions, Investment Opportunities, and Management Ownership. Journal of Finance, 51(4), 1227-1246.

Mcconnell, J. J., \& Muscarella, C. J. (1985). Corporate Capital Expenditure Decisions and the Market Value of the Firm. Journal of Financial Economics, 14(3), 399-422.

Mcgrattan, E. (1999). Maintenance and Repair: Too Big to Ignore. Federal Reserve Bank of Minneapolis Quarterly Review, 23(4), 2-13.

Mcwilliams, A., \& Smart, D. L. (1993). Efficiency V Structure-Conduct-Performance: Implications for Strategy Research and Practice. Journal of Management, 19(1), 63-78.

Mello, A. S., \& Wang, M. (2012). Globalization, Product Market Competition and Investment, Proceedings. Presented at the AFA (American Finance Association) 2013 San Diego Meetings Paper.

Modigliani, F., \& Miller, M. H. (1963). Corporate Income Taxes and the Cost of Capital: a Correction. American Economic Review, 53(3), 433-443.

Mutlu, C., Essen, V., Peng, M., \& Saleh, S. (2016). Agency Theory and Corporate Governance in China: a Meta-Analysis. Journal of Management Studies, 55(6), 943-979. 
Ahmad Cahyo Nugroho \& Jol Stoffers/ Market Competition and Agency Problem: a Study ...

Myers, S. C., \& Majluf, N. S. (1984). Corporate Financing and Investment Decisions When Firms Have Information that Investors Do Not Have. Journal of Financial Economics, 13(2), 187-221.

Nugroho, A. C., Firdaus, M., Andati, T., \& Irawan, T. (2018). Investment Decision in the Agency Theory Framework. Mix: Jurnal Ilmiah Manajemen, 8(1), 16-32.

Opler, T. C., \& Titiman, S. (1994). Financial Distress and Corporate Performance. The Journal of Finance, 49(3), 1015-1040.

Rubinstein, A., \& Tirole, J. (1989). Theory of Industrial Organization. Economica, 56(223), 401402.

Salitskiy, I. (2013). Optimal Dynamic Contracts in Financial Intermediation: with an Application to Venture Capital Financing. Unpublished Thesis. Stanford: Stanford University.

Santalo, J., \& Becerra, M. (2008). Competition from Specialized Firms and the Diversification-Performance Linkage. Journal of Finance, 63(2), 851-883.
Shima, K. (2016). Negative Uncertainty Sensitivity of Investment and Market Structure. Economics Letters, 147, 93-95.

Stoughton, N. M., Wong, K. P., \& Yi, L. (2017). Investment Efficiency and Product Market Competition. Journal of Financial and Quantitative Analysis, 52(6), 2611-2642.

Sundaramurthy, C., \& Lewis, M. (2003). Control and Collaboration: Paradoxes of Governance. Academy of Management Review, 28(3), 397-415.

Worthington, A., \& Higgs, H. (2004). Random Walks and Market Efficiency in European Equity Markets. Global Journal of Finance and Economics, 1(1), 59-78.

$\mathrm{Xu}, \mathrm{J}$. (2012). Profitability and Capital Structure: Evidence from Import Penetration. Journal of Financial Economics, 106(2), 427-446.

Young, M. N., Peng, M. W., Ahlstrom, D., Bruton, G. D., \& Jiang, Y. (2008). Corporate Governance in Emerging Economies: a Review of the Principal-Principal Perspective: Review Paper. Journal of Management Studies, 45(1), 196-220. 